\title{
Employee Behavioral Commitment of BLU UPTD Trans Semarang
}

\author{
Puji Winarsih $^{\bowtie}$, S Martono \\ Management Department, Faculty of Economics, Universitas Negeri Semarang, Semarang, Indonesia
}

\begin{tabular}{l} 
Article Information \\
\hline Article History: \\
Received January 2020 \\
Approved February 2020 \\
Published June 2020 \\
\hline Keywords: \\
Work Life Balance, Job \\
Satisfaction, Engagement, \\
Work Motivation, Com- \\
mitment. \\
\hline
\end{tabular}

\section{INTRODUCTION}

Employees as human resources are the key to organizational success (Susanti \& Palupiningdyah, 2016). Good human resources will be needed by the company in the long term. This means that the company needs employees who are able to realize the company's goals. Human resources are an important factor for organization survival, so, effort are needed to motivate and maintain qualified human resources as assets or human capital and key partners for business actors in the production of goods and services (Harini et al., 2019).

Over the past ten years, the study of commitment has advanced in many different directions. Various disciplines have adopted the topic as a theme in their research and it has offered new and significant insights. As long as the organiza- tion is able to attract the right employees and has provided an appropriate work environment, employee commitment will be greatly influenced by interactions that occur between colleagues and their direct managers and seniors. Relationships between organizations and employees are considered to be the same as other types of relationships. If individuals in a company that is human resources can run effectively, the company continues to run effectively (Ranihusna, 2013). Every organization must have a strategy to be able to retain qualified employees. Qualified employees will be able to make a major contribution to the progress of the organization which will then be bound and empowered by the organization. Bound employees will stay in the organization for a long time (Raharjo \& Witiastuti, 2016).

Compared to other factors, human resources are the most valuable assets. The role of hu-

(C) 2020 Universitas Negeri Semarang

\footnotetext{
Correspondence Address:

L2 Building, 1st Floor, Faculty of Economics, Universitas Negeri Semarang

Jalan Taman Siswa, Sekaran, Gunungpati, Semarang, 50229

E-mail: pujiwinarzih@gmail.com
} e-ISSN 2252-6552 
man resources will determine the success and failure of an organization in achieving its stated vision and mission. Therefore, employees are the key determinant of the company's success. The company's success is judged by the company's success in achieving the company's goals (Nahdluddin \& Maftukhah, 2015).

Every company wants its employees to have high commitment. High commitment can encourage employees to work well. A person who joins an organization in a company is required to commit themselves (Ghoniyah \& Masurip, 2011). With the encouragement and enthusiasm possessed by employees is expected to increase commitment to the company. Conversely, if employees feel unmotivated and unenthusiastic in working, it will have an impact on organizational commitment at the company will decrease (Purnamasari \& Palupiningdyah, 2012).

Organizational commitment shows one's confidence and support and loyalty to the values and goals to be achieved by the organization. Strong organizational commitment will cause individuals to try to achieve organizational goals, think positive and try to do the best for the organization. This happens because individuals in organizations will feel they have an organization. While low organizational commitment will cause the individual to only be concerned with himself or his group so that in the end the performance of the individual will be low in the organization. Companies must incur costs to find new workers, and or train existing workers to replace employees who leave. Therefore, companies must avoid an increase in turnover activities by considering the sustainability of the company's operations (Susanti \& Palupiningdyah, 2016).

Employee commitment is grouped in the form of three bases or mindset that is affective, normative, and sustainable, which reflects the emotional ties, perceived obligations, and costs that must be sacrificed in relation to the targets of each employee (Allen \& Meyer, 1990). Organizational commitment is a behavior owned by employees that reflects the behavior of the company in favor of accepting company goals or the values adopted by the company. According to Meyer and Herscovitch (2001) commitment is the power that binds an individual to actions that are relevant to one or more targets. The concept of commitment in the workplace relates to employee behavior to create and maintain a workforce and make a positive contribution to the organization. Organizational commitment is an individual aspect that has recently become a strategic issue in achieving superior HR. This can be un- derstood because organizational commitment is an attitude and behavior that must be considered by the organization (Sudarma, 2012).

The company's success in achieving its goals is inseparable from the commitment of employees which can be seen as a condition where an employee or individual is in favor of an organization, and intends to maintain membership in the organization (Masrukhin, 2014). Studies in the area of commitment also include the conceptualization of commitment to work, work groups, representative company parties, and the work itself (Ghosh \& Swamy, 2014). Employee commitment is basically inseparable from the balance between work life and life outside of work. Life satisfaction is also an important thing to notice.

In modern organizational life, employee life satisfaction is a measure of the level of organizational maturity and a sign that the organization is well managed. (Sulimah \& Wulansari, 2018). So when employees have low commitment, it needs to be traced back to Work Life Balance (WLB). Work life balance must be maintained effectively to ensure that all employees have the potential and are free from stress and work tension. Employees believe that the presence of quality work life will make employees feel safe, relatively satisfied and able to grow so that employees are able to develop (Nguru, 2018). Research according to Berk and Gundogmus (2018) states that WLB has a significant influence on employee commitment, so it can be said that when employees are able to work without ignoring all aspects of work life, personal, family, spiritual, and social, it will encourage these employees to have a commitment. On the other hand, research conducted by Rene (2018) found that WLB did not have a significant effect on employee commitment. So it needs to be reviewed again related to the research gap between WLB and employee commitment. Another factor that is expected to influence the commitment of Trans Semarang BLU employees is employee satisfaction. That is because satisfaction is a general or global affective reaction that can be seen from the role of individuals undergoing their work. Job satisfaction is a pleasant emotional state of individual related to his/her job. Job satisfaction reflects the individual feeling towards his/her job (Martono et al., 2018). Evaluation results show satisfaction can be seen from the work experience of employees by comparing what employees expect from their work and from the facts that actually occur received by the employees themselves (Locke, 1969).

Factors that influence employee commitment other than WLB and job satisfaction are 
employee Engagement. Employee engagement is an important concept in organizational behavior and is received as a significant concern ( $\mathrm{Ha}$ naysha, 2016). Employee engagement is also the creation of an environment where employees will be motivated to get a touch of attention and is strongly associated with better work improvement (Harini et al., 2019).

In addition to employee engagement, the next factor influencing commitment according to researchers is motivation. According to $\mathrm{Ha}$ sanah et al. (2016) motivation and commitment in organizations is a crucial meeting, both in the public sector and in the private sector. Motivation functions as a driving force from within individuals to carry out certain activities in achieving goals. If employees have high work motivation, it will foster a sense of reluctance to leave the company.

Research related to WLB, job satisfaction, engagement, and motivation towards employee commitments is mostly done in the manufacturing sector, the banking sector, and educators. Whereas the role of other sectors such as the transportation service sector also needs to be investigated considering that in that sector the role of employees is very important in regulating transportation mobilization. Transportation is a very fundamental thing. Without transportation as a means of support, it can no longer be expected to achieve satisfactory results in the economic development efforts of a country (Khadir, 2006). Companies really need to maintain and maintain the commitment of employees because the higher the level of employee commitment, the longer the employee has the desire to remain in the company (Nuur \& Sudarma, 2017)

Based on Peraturan Walikota Semarang No. 3/2013 it is explained that the BLU UPTD Trans Semarang as a public transportation service provider is expected to become a professional public transportation service organization and meet the development of Semarang City as a Metropolitan City. So the existence of these regulations indirectly requires BLU UPTD Trans Semarang employees to always optimize their performance to help the government in realizing professional services. Nevertheless, a work commitment is needed to participate in realizing the goals of the organization. Phenomenon in the field shows that BLU UPTD Trans Semarang employees have low commitment because they have relatively high employee turnover.

Several problems have been found, both based on observations and the results of pre- vious research analyzes, the researcher is interested in conducting research related to the effect of WLB, job satisfaction, employee engagement, and motivation on employee commitment. From this it can be said that research that examines work life balance, job satisfaction, engagement, motivation and commitment of employees in the BLU UPTD Trans Semarang has never been done in the transportation services sector, so researchers are interested in researching about it.

\section{Hypotheses Development}

Work life balance is a balanced that must be owned by employees to facilitate achieving organizational goals. Employees who have a balance between work and personal activities will bring up conditions where employees reach a point of comfort. When employees are in the comfort zone, it is inevitable that employees feel welcome and there is a feeling of wanting to stay. The feeling of wanting to stay is manifested through pride in the organization, a sense of responsibility so that it obeys organizational rules, and will tell others that the organization is giving employees what they expect. So employees who have WLB will tend to have a sense of belonging to the organization so that it raises high commitment. In WLB, organizations must allow employees to work longer hours a week to get free or free time and provide more flexible work plans as a form of appreciation for employees. Organizations must also provide support for facilities relating to recreation and provide free access to specific sports clubs (Nguru, 2018).

This is consistent with research conducted by Oktaviani and Budiono (2018) that work life balance has a positive and significant relationship to employee commitment. The research was supported by Berk and Gundogmus (2018) that work life balance has a positive and significant relationship to employee commitment.

H1: The better work life balance will increase employee commitment

Job satisfaction can be one factor that can affect organizational commitment (Ramadhani \& Khoirunnisa, 2011). Organizational commitment is strongly influenced by the extent to which his work can provide satisfaction to him. Satisfied employees will have a positive impact on the company, because it will not bring up demonstrations as a form of employee dissatisfaction. If employees feel satisfied with the work then they will be more committed to the company (Puspitawati \& Riana, 2014). 
H2: The better job satisfaction will increase employee commitment

Employee engagement is a form of relationship between employees and the company. Employees who have a bond with the company usually start with a work contract and other work agreements. Employee engagement has an energetic and effective sense of relationship with employee work activities and they see themselves as being able to handle their job demands well (Schaufeli \& Bakker, 2004). In the sense that employees have job demands, because with this as a manifestation of the company giving reciprocity to employees. Employees who have a high work engagement can be seen from the roles they play and the burden placed on the company. Employees who have a high Engagement will have an impact on the high commitment of the employees themselves. This is consistent with research conducted by Hanaysha (2016) which shows that work engagement has a positive relationship with employee commitment. The higher the work engagement that is owned by employees, the higher the commitment that is in the employees themselves.

$\mathrm{H} 3$ : The better the Engagement, it will increase employee commitment

Motivation is the provision of motive power that creates the excitement of one's work, so that they want to work together, work effectively and be integrated with all their power and efforts to find satisfaction. The purpose of motivating employees to create morale and increase productivity. Highly motivated employees will understand what they are doing, are passionate about working, work happily without pressure and are able to give the best results. Giving encouragement in the form of motivation from superiors to subordinates which is done continuously will create a good relationship between superiors and subordinates. Employees who are given encouragement will feel cared for, valued, and feel involved in organizational activities, then commitment will grow towards the organization.

When a person has high motivation, the higher the commitment the employee has. This is in line with the thinking of Salleh, Sufiyan, Zahari, Shafini, Said, Rapidah, and Mara (2016) which states that motivation is one of the things that makes employees committed. Motivation also has a positive relationship with commitment. $\mathrm{H} 4$ : The better motivation will increase employee commitment
The research framework proposed in this study is as follows:

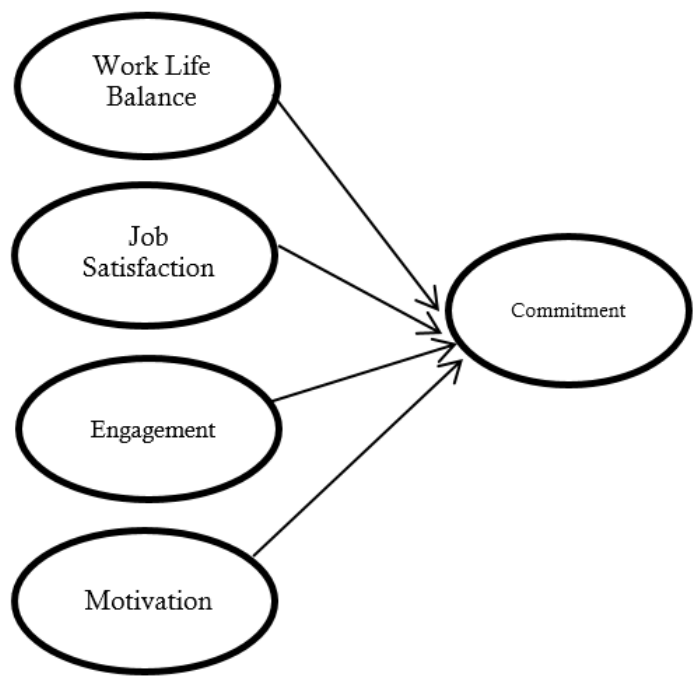

Figure 1. Research Model

\section{METHOD}

The population in this study were BLU UPTD Trans Semarang employees with a total of 187 employees. Sampling in this study uses probability sampling, where the sampling used is proportionate random sampling. So that a sample of 128 employees was obtained. This type of research is quantitative research. Sources of data in this study are primary data with 1-5 Likert scale. The instrument test uses a validity test and a reliability test.

\section{RESULT AND DISCUSSION}

Based on data from the results of research that has been done from the distribution of questionnaires, the information obtained about the characteristics of respondents according to gender, age and years of service. Characteristics of respondents according to gender of 128 employees mostly dominated by male employees by $60.16 \%$, while female employees by $39.84 \%$. The work in the BLU UPTD Trans Semarang is mostly done by male employees compared to work done by female employees. Data processing according to the age of the respondents showed that most were dominated by employees aged 24-29 years with a percentage of $42.19 \%$, and the lowest percentage of $4.69 \%$ with a total of 6 employees aged $42-47$ years. The second highest percentage of $23.44 \%$ is dominated by employees aged 18-23 years. Employees aged 30-35 years had a percentage of $21.09 \%$. In addition, em- 
ployees aged 36-41 years were 11 employees with a percentage of $8.59 \%$. So, it can be concluded that employees who work at BLU UPTD Trans Semarang are classified as productive age.

Data processing according to tenure can be explained that most have 1-3 years of service with a percentage of $53.12 \%$ and the lowest percentage of $4.69 \%$ are employees who have a service life of 7-8 years and 9-10 years. Employees with 4-6 years of service have a percentage of $23.44 \%$, while the percentage of 14.06 is dominated by employees with tenure of less than 1 year.

Based on the above results, it can be concluded that employees with 1-3 years of service have enough experience, skills and are able to explore the work they are involved in compared to new employees. Even though employees who have 4-6 years of service are only $23.44 \%, 7-8$ years of service, 9-10 years each are only $4.69 \%$, and employees with less than 1 year of service are only $14.06 \%$ not it means that the employees only have work experience related to the work they do compared to employees who have a work period of 1-3 years.

Data processing based on the characteristics of the respondents according to the last education of the respondents can be explained that of the 128 employees who became respondents most of them have attended high school / equivalent with a percentage of $54.69 \%$, and the lowest percentage of $3.12 \%$ is the employee who has the last education at the level Middle school / equivalent. Employees with the last level S1 / equivalent have a percentage of $34.38 \%$, while the percentage of 7.81 are employees with the most recent education other than above.

Based on the above results it can be concluded that employees with the highest level of education in senior high school / equivalent have had enough provisions and are mature enough to be able to work at BLU UPTD Trans Semarang. Data processing based on the characteristics of respondents according to marital status can be explained that most are married with a percentage of $50 \%$. However, employees with unmarried status also have a large percentage of $47.66 \%$. While the remaining $2.34 \%$ are widowed / widowed. So it can be concluded that half of the UP Semarang BLU UPTD Trans Semarang employees are married or can be said to be married and have life partners.

\section{Validity test}

Validity test is done by comparing the value of $r$ count with $r$ table for degree of freedom (df) $=n-2$ with sig $5 \%$, in this case $n$ is the number of samples. If in the Corrected Item-Total
Correlation output display the $r$ value is $\geq \mathrm{r}$ table and the value is positive, then the question item is declared valid (Sanusi, 2017: 77). The higher the level of validity of an instrument, the more precise the instrument. This study the number of samples $(n)=128$ and the magnitude of $\mathrm{df}$ can be calculated $128-2=126$, with $\mathrm{df}=126$ and alpha 0.05 so that the product moment $r$ obtained is 0.174 . If $\mathrm{r}$ arithmetic is greater than $\mathrm{r}$ table and a positive value, then the item question or indicator is declared valid.

Table 1. Result of Validity Test

\begin{tabular}{llll}
\hline Variable & r hitung & $\mathbf{r}$ table & Criteria \\
\hline $\begin{array}{l}\text { Work Life } \\
\text { Balance }\end{array}$ & 0.848 & 0.174 & Valid \\
Job & 0.835 & 0.174 & Valid \\
Satisfaction & & & \\
Engagement & 0.919 & 0.174 & Valid \\
Motivation & 0.698 & 0.174 & Valid \\
Commitment & 0.911 & 0.174 & Valid \\
\hline
\end{tabular}

Based on the validity test conducted by researchers on 128 employees it was found that the research question items were said to be valid because the $r$ value was greater than the $r$ table.

\section{Reliability Test}

Reliability test is used to measure the stability and consistency of an instrument in measuring a variable. A questionnaire is said to be reliable or reliable if a person's answer to a statement is consistent or stable from time to time. So the cronbanch alpha coefficient value $>0.70$ is an indicator that the questionnaire is reliable (Ghozali, 2011).

Table 2. Result of Reliability Test

\begin{tabular}{|c|c|c|c|}
\hline Variable & $\begin{array}{l}\text { Cronbach's } \\
\text { Alpha }\end{array}$ & $\begin{array}{l}\text { Minimal } \\
\text { Cronbach's } \\
\text { Alpha }\end{array}$ & Criteria \\
\hline $\begin{array}{l}\text { Work Life } \\
\text { Balance }\end{array}$ & 0.755 & 0.70 & Reliable \\
\hline $\begin{array}{l}\text { Job } \\
\text { Satisfaction }\end{array}$ & 0.743 & 0.70 & Reliable \\
\hline Engagement & 0.730 & 0.70 & Reliable \\
\hline Motivation & 0.714 & 0.70 & Reliable \\
\hline Commitment & 0.707 & 0.70 & Reliable \\
\hline
\end{tabular}

The reliability test in this study showed that the variable work life balance, job satisfacti- 
on, Engagement, and commitment levels were all reliable with a Cronbach's Alpha value of more than 0.70 .

\section{Coefficient Determination Test (R2)}

The coefficient of determination test aims to measure how far the ability of the independent variables simultaneously affect the dependent variable. The following results from the coefficient of determination test (R2).

Table 3. Analysis of the Coefficient Determination

\begin{tabular}{ll}
\hline Variable & Adjusted R-square \\
\hline Commitment & 0.773 \\
\hline
\end{tabular}

Adjusted R Square value of 0.773 means that $77.3 \%$ variation in organizational commitment can be explained by variations of the four independent variables namely work life balance, job satisfaction, employee engagement, and motivation. While the remaining $23.7 \%$ is explained by other reasons outside the research model.

\section{Hypothesis Testing \\ Multiple Linear Regression Test}

This analysis is used to determine the effect of work life balance, job satisfaction, engagement, motivation and employee commitment. If the value of sig $<0.05$ or $\mathrm{t}$-count $>\mathrm{t}$-table then Ho is rejected, thus the independent variable can explain the dependent variable in the model. Conversely, if the value of sig $>0.05$ or $t$-count $<\mathrm{t}$-table then Ho is accepted, thus the independent variable cannot explain the dependent variable or in other words means there is no influence between the two variables tested. The results of the study can be seen in Table 4.

All variables have significance values below 0.05 . Then it can be concluded that the organizational commitment is influenced by work life balance, job satisfaction, engagement, and motivation.From this equation, it can be interpreted that the regression coefficient value of work life balance is 0.261 is positive. From the t test, a significance value of 0.002 was obtained with a significance level of 0.05 , which means that sig count <sig table, it can be concluded that $\mathrm{H} 1$ which states that the higher the level of work life balance will cause the higher organizational commitment of BLU UPTD Trans Semarang employees, was accepted.

The regression coefficient value for the job satisfaction of 0.224 is positive, meaning that the higher the characteristics of work, salary, opportunities, superiors, and colleagues, the higher the commitment of employees to the organization. From the $t$ test, it was obtained the significance value of 0.003 with a significance level of 0.05 , which means that sig count < sig table, then it can be concluded that $\mathrm{H} 2$ which stated that the higher the level of job satisfaction would cause the higher organizational commitment of BLU UPTD Trans Semarang employees, was accepted.

The value of the regression coefficient for employee engagement variables of 0.343 is positive which means that the higher the enthusiasm (vigor), dedication, and absorption, the higher the commitment of employees to the organization. From the t test, a significance value of 0.001 was a significance level of 0.05 , which means that sig count <sig table, it can be concluded that H3 which states that the higher level of employee engagement will cause higher organizational commitment of BLU UPTD Trans Semarang employees, was accepted.

The regression coefficient value for the work environment variable of 0.243 is positive which means the better the atmosphere of the workplace, relationships with colleagues, and facilities available, the higher the commitment of employees to the organization. From the test, a significance value of 0,000 was obtained with

Table 4. Hypothesis Test

Coefficients $^{\mathrm{a}}$

\begin{tabular}{lllllll}
\hline \multirow{2}{*}{ Model } & \multicolumn{2}{l}{ Unstandardized Coefficients } & Standardized Coefficients & & \multirow{2}{*}{ Sig. } \\
\cline { 2 - 5 } & $\mathbf{B}$ & Std. Error & Beta & & \\
\hline 1 & (Constant) & 5.191 & 1.544 & & 3.362 & 0.001 \\
& Work Life Balance & 0.261 & 0.084 & 0.253 & 3.103 & 0.002 \\
& Job Satisfaction & 0.224 & 0.075 & 0.206 & 2.999 & 0.003 \\
& Engagement & 0.343 & 0.100 & 0.336 & 3.418 & 0.001 \\
& Motivation & 0.243 & 0.061 & 0.216 & 4.013 & 0.000 \\
\hline
\end{tabular}

$\mathrm{Y}=5.191+0.261$ Work Life Balance +0.224 Job Satisfaction + 0.343 Engagement + 0.243 Motivation 
a significance level of 0.05 , which means that sig count <sig table, it can be concluded that $\mathrm{H} 4$ which states that the higher the level of motivation will cause the higher organizational commitment of BLU UPTD Trans Semarang employees, accepted.

\section{Effect of Work Life Balance on Commitment}

Based on data analysis in this study it can be seen that work life balance has an influence on employee commitment to the organization. This is indicated by a coefficient value of 0.261 and a significance value of 0.002 . The direction of a positive relationship shows that when employees have a work life balance that is able to balance their personal life and work life well, it will increase employee commitment, and vice versa, when employees have a low work life balance that is unable to balance personal life and work life, then commitment employees in the organization will decrease. Significant results indicate that work life balance has an influence on the level of employee commitment to the organization. The results of this study are consistent with research conducted by Berk and Gundogmus (2018) that work life balance has a positive effect on organizational commitment. In addition, this study also supports research conducted by Oktaviani (2018) that work life balance has a positive and significant effect on organizational commitment.

\section{Effect of Job Satisfaction on Commitment}

Based on data analysis in this study it can be seen that job satisfaction has an influence on employee commitment to the organization. This is indicated by a coefficient value of 0.224 and a significance value of 0.003 . The direction of a positive relationship shows that when employees feel satisfied with the company it will increase employee commitment to the company. When employees do not feel satisfaction will reduce the employee's commitment. Significant results indicate that job satisfaction has an influence on the level of employee commitment to the organization. The results of this study are consistent with research conducted by Berk \& Divine (2017) that job satisfaction has a positive effect on organizational commitment. In addition, this study also supports research conducted by Lizote et al., (2017) that job satisfaction has a positive and significant effect on organizational commitment.

\section{Effect of Engagement on Commitment}

Based on data analysis in this study it can be seen that job satisfaction has an influence on employee commitment to the organization. This is indicated by a coefficient value of 0.343 and a significance value of 0.001 . The direction of the positive relationship shows that when employee engagement increases, it will increase employee commitment to the organization. Significant results indicate that employee engagement has an influence on the level of employee commitment to the organization. The results of this study are consistent with research conducted by Hanaysha (2016) and Harini et al., (2019) that work engagement has a positive effect on organizational commitment.

\section{Effect of Motivation on Commitment}

Based on data analysis in this study it can be seen that job satisfaction has an influence on employee commitment to the organization. This is indicated by a coefficient value of 0.243 and a significance value of 0.000 . The direction of a positive relationship shows that when employee motivation increases, it will increase employee commitment to the organization, and vice versa when employee motivation decreases it will reduce employee commitment to the organization. Significant results indicate that motivation has an influence on the level of employee commitment to the organization. The results of this study are consistent with research conducted by Hasanah et al., (2016) and Salleh et al. (2016) that motivation has a positive effect on organizational commitment.

\section{CONCLUSION AND RECOMMENDATION}

Based on data analysis and discussion of research results, it can be concluded that work life balance can increase the organizational commitment of UP Semarang Trans Semarang employees. High organizational commitment to employees will be created when employees have a balance between personal life and work life. This means that the higher the level of work life balance will increase employee commitment to the organization, conversely the lower the work life balance will reduce employee commitment. Job satisfaction can increase the commitment of UPTD Trans Semarang BLU employees. High organizational commitment to employees will be created when employees feel satisfied with the company. This means that the higher the level of employee job satisfaction will increase employee commitment.

Employee engagement can increase organizational commitment of BLU UPTD Trans Semarang's employees. High organizational commitment will be created if employees have 
the vigor, dedication, and absorption. This means that the higher level of employee engagement will increase employee commitment to the organization. Motivation can increase the commitment of employees of BLU UPTD Trans Semarang's employees. High organizational commitment to employees will be created when employees have the motivation to work. This means that the higher the motivation of employees to work it will increase employee commitment to the organization, conversely the lower the motivation of employees will reduce employee commitment to the organization.

Managerial implementation of this study that companies should provide more motivation to all employees, by providing work motivation in the form of the need for achievement such as employees being rewarded at work, giving employees the opportunity to work together with other employees in completing work and so on so that employees are very encouraged to stay in the company. The company should meet the needs as a supporter of employees in working so as to create high employee satisfaction. In addition the company must be able to make employees feel attached to the company in order to create comfort in working and have a high sense of ownership. Suggestions for further researchers are to be able to broaden the scope of research, test the same variables in different places and add research variables that could affect employee commitment to the company.

\section{REFERENCES}

Allen, N. J., \& Meyer, J. P. (1990). The Measurement and Antecedents of Affective, Continuance and Normative Commitment to Organization. Journal Of Occupational Psychology, 63(1), 1-18.

Berk, C., \& Gundogmus, F. (2018). The Effect of Work-Life Balance on Organizational Commitment. Academy of Strategic Management Journal, 13(2), 137-159.

Ghoniyah, N., \& Masurip. (2011). Peningkatan Kinerja Karyawan melalui Kepemimpinan, Lingkungan Kerja dan Komitmen. Jurnal Dinamika Manajemen, 2(2), 118-129.

Ghosh, S., \& Swamy, D. R. (2014). Open Access A Literature Review on Organizational Commitment - A Comprehensive Summary. Jounal of Enginering Research and Applications, 4(12), 4-14.

Ghozali, I. (2011). Aplikasi Analisis Multivariate dengan Program IBM SPSS 19 (Edisi 5). Semarang: Badan Penerbit Undip.

Hanaysha, J. (2016). Testing the Effects of Employee Engagement, Work Environment, and Organizational Learning on Organizational Commitment. Procedia - Social and Behavioral Sciences,
229, 289-297.

Harini, S., Luddin, M. R., \& Hamidah. (2019). Work Life Balance, Job Satisfaction, Work Engagement and Organizational Commitment Among Lecturer. Journal of Engineering and Applied Sciences.

Hasanah, N., Isa, M., Romle, A. R., Udin, M. M., Zahirah, S., Zahid, M., Mohamad, H. (2016). Relationship between Motivation and Commitment on Job Performance among Employees in Higher Education from Students' Perspective. World Appled Sciences Journal, 34(3), 400-407.

Locke, E. A. (1969). What is Job Satisfaction?. Organizational Behavior and Human Performance, 4(4), 309-336.

Martono, S., Khoiruddin, M., \& Wulansari, N. A. (2018). Remuneration Reward Management System as a Driven Factor of Employee Performance. International Journal of Business \& Society, 19, 535-545.

Masrukhin, M. A. (2014). Praktik Sistem Kerja Berkinerja Tinggi terhadap Komitmen Afektif. Jurnal Dinamika Manajemen, 5(1), 74-83.

Meyer, J. P., \& Herscovitch, L. (2001). Commitment in the Workplace toward a General Model. $\mathrm{Hu}$ man Resources Management Review, 11(3), 299326.

Nahdluddin, M., \& Maftukhah, I. (2015). Pengaruh Motivasi Kerja, Budaya Organisasi dan Kualitas Kehidupan Kerja terhadap Kinerja Karyawan. Management Analysis Journal, 4(3), 219228.

Nguru, R. M. (2018). Influence of Work Life Balance on Employee Commitment in Parastatals: A Case Study of National Hospital Insurance Fund in Nakuru, Kenya. International Journal of Economics, Commerce and Management, 6(5), 378-407.

Nuur, M. Z. I., \& Sudarma, K. (2017). Pengaruh Keadilan Distributif, Keterlibatan Kerja dan Kepuasan Kerja pada Komitmen Berkelanjutan. Management Analysis Journal, 6(1).

Oktaviani, H., \& Budiono. (2018). Pengaruh Work Life Balance dan Perceived Organizational Support terhadap Turnover Intention melalui Organizational Commitment sebagai Variabel Intervening pada PT Berlian Jasa Terminal Indonesia. Jurnal Ilmu Manajemen, 6(3), 58-72.

Purnamasari, \& Palupiningdyah. (2012). Pengaruh Person-Organization Fit dan Motivasi Kerja pada Komitmen Organisasional dengan Kepuasan Kerja sebagai Variabel Mediasi. Management Analysis Journal, 1(2), 120-128.

Puspitawati, N. M., \& Riana, I. M. (2014). Pengaruh Kepuasan Kerja terhadap Komitmen Organisasional dan Kualitas Layanan. Jurnal Manajemen Strategi Bisnis dan Kewirausahaan, 8(1), 68-80.

Raharjo, C. D., \& Witiastuti, R. S. (2016). Pengaruh Kepemimpinan Transformasional terhadap Keterikatan Kerja melalui Keadilan Organisasional sebagai Variabel Mediasi. Management Analysis Journal, 5(4), 347-361. 
Ramadhani, N. A., \& Khoirunnisa, R. N. (2011). Hubungan antara Kepuasan Kerja dengan Komitmen Organisasi pada Polisi Wanita. Jurnal Psikologi, 5(2), 1-6.

Ranihusna, D. (2013). Efek Rantai Motivasi pada Kinerja Karyawan. Jurnal Dinamika Manajemen, 1(2), 90-103.

Rene, R. (2018). Pengaruh Work-Life Balance terhadap Komitmen Organisasi, Kepuasan Kerja, dan Motivasi Kerja. Jurnal Manajemen dan Bisnis Surabaya, 16(4).

Salleh, S. M., Suffian, A., Zahari, M., Shafini, N., Said, M., Rapidah, S., Mara, U. (2016). The Influence of Work Motivation on Organizational Commitment in the Workplace. Journal of Applied Environmental and Biological Sciences, 6, 139-143.

Schaufeli, W., \& Bakker, A. (2004). UWES: Utrecht Work Engagement Scalee, (December). Occu- pational Health Psychology Unit Utrecht University. Suaarjna, A. A., Putra, I. K. M., \& Susilawati, N. L. N. A. S. (2016). Pengaruh Motivasi Kerja dan Kepuasan Kerja terhadap Komitmen Organisasi serta Dampaknya terhadap Kinerja Pegawai PLN Rayon Gianyar di Kabupaten Gianyar. Jurnal Bisnis dan Kewirausahaan, 12(1), 1-11.

Sudarma, K. (2012). Mencapai Sumber Daya Manusia Unggul (Analisis Kinerja dan Kualitas Pelayanan). Jurnal Dinamika Manajemen, 3(1), 76-83.

Sulimah, S., \& Wulansari, N. A. (2018). When Conflict be a Trigger of Depression: between Job and Life Satisfaction. Jurnal Dinamika Manajemen, 9(2), 238-249.

Susanti, \& Palupiningdyah. (2016). Pengaruh Kepuasan Kerja dan Komitmen Organisasi terhadap Kinerja Karyawan dengan Turnover Intention sebagai Variabel Intervening. Management Analysis Journal, 5(1), 77-86. 